\title{
Evolution of the physical and physiological quality of soybean seeds during processing ${ }^{1}$
}

\author{
Tana Balesdent Moreano ${ }^{2 *}$, Odair José Marques ${ }^{3}$, Alessandro Lucca Braccini ${ }^{4}$, \\ Carlos Alberto Scapim ${ }^{4}$, José de Barros França-Neto ${ }^{5}$, Francisco Carlos Krzyzanowski ${ }^{5}$
}

\begin{abstract}
Seed processing or conditioning is important for improving soybean seed lot quality as it improves the physical characteristics by eliminating inert materials, weed and non-standard seeds and increases physiological quality. The objective of this study was to evaluate the effect of processing on physical and physiological qualities of soybean seed, before and after each equipment and transport system, during processing in a Seed Processing Plant. Samples of six cultivars were obtained during processing while seeds passed through each machine, totaling fifteen sampling sites. The experimental design was entirely randomized, treatments arranged in 15 × 6 factorial scheme, with 10 replications. Characteristics evaluated were germination; vigor by accelerated aging test; tetrazolium test for viability (TZ 1 to 5), vigor (TZ 1 to 3), weathering damage (TZ 3), mechanical damages (TZ 2 to 8), stinkbug damages (TZ 2 to 8) and moisture content. Results showed that processing improves the physiological and physical qualities of soybean seeds and enhances average quality seeds. The equipment and the system of transport (lifts and conveyor belts) used in this study did not cause mechanical damages to the seeds; the mechanical damages were mostly detected in larger seeds and stinkbug damages were found in smaller seeds; and seeds with weathering damage were neither eliminated nor reduced by any processing line.
\end{abstract}

Index terms: Glycine $\max ($ L.) Merrill, mechanical damage, stinkbug damage, vigor, weathering damage.

\section{Qualidade física e fisiológica de sementes de soja durante o beneficiamento}

\begin{abstract}
RESUMO - O beneficiamento de sementes tem uma importância fundamental na melhoria da qualidade de lotes de sementes de soja, podendo melhorar as caracacterísticas físicas pela eliminação de materiais inertes, sementes de plantas daninhas e sementes fora de padrão e permitindo incremento na qualidade fisiológica. Objetivou-se com este trabalho avaliar a evolução das características físicas e fisiológicas das sementes de soja ao longo da linha de beneficiamento, sendo avaliadas seis cultivares em quinze pontos de amostragem. Delineou-se em DIC, em fatorial 15 x 6 e 10 repetições. Avaliou-se germinação; vigor no envelhecimento acelerado; viabilidade pelo teste de tetrazólio (TZ classes 1 a 5); vigor (TZ classes 1 a 3); deterioração por umidade (TZ classe 3); danos mecânicos totais (TZ classes 2 a 8); danos por percevejos (TZ classes 2 a 8); e grau de umidade. Concluiu-se que o beneficiamento melhora as qualidades física e fisiológica das sementes, sendo a eficiência acentuada nas sementes de qualidade mediana. O sistema de transporte (elevadores e correias transportadoras) não promoveu danos mecânicos às sementes. As sementes maiores tendem a ser mais afetadas pelos danos mecânicos, e menores apresentam mais danos por percevejos. As sementes deterioradas por umidade não são eliminadas em nenhuma etapa do beneficiamento.
\end{abstract}

Termos para indexação: Glycine max (L.) Merrill, dano mecânico, dano por percevejo, deterioração por umidade, vigor.

\section{Introduction}

The utilization of seeds from improved cultivars with a high productive potential and with desirable industrial and agronomic characteristics is the foundation of modern agriculture. This advance, deriving from the plant breeding,

\footnotetext{
${ }^{1}$ Submitted on $05 / 09 / 2018$. Accepted for publication on 06/06/2018. ${ }^{2}$ BASF S.A., 04794-000 - Morumbi, São Paulo, SP, Brasil. ${ }^{3}$ Instituto de Ciências Agrárias, Universidade Federal de Uberlândia, 38500-000 Monte Carmelo, MG, Brasil.
}

${ }^{4}$ Programa de Pós-graduação em Agronomia, Universidade Estadual de Maringá, 87020-900 - Maringá, PR, Brasil.

${ }^{5}$ Embrapa Soja, Caixa Postal 231, 86001-970 - Londrina, PR, Brasil.

*Corresponding author <tana.moreano@gmail.com> 
combined with adequate management techniques, has made it possible to obtain more productive cultivars. Schuch et al. (2009) working with two different soybean seed lots with high and low vigor, found out that the plants from seeds of high vigor were $25 \%$ more productive than those from low vigor seeds.

The fundamental procedures for the production of high quality seeds include: choosing the most appropriate production region (considering agronomic, structural, and commercial aspects); selection of areas destined for production (considering isolation, sanitary conditions, presence of weeds, location and access, topography, soil and climate characteristics); establishment of a crop rotation plan; origin and quality of basic seeds; management of the area (soil preparation system, time of year and care during sowing and crop handling); inspections and eradication of undesirable plants; control of pests and diseases; harvest, drying, and processing; storage and transport conditions for the product; establishment of a quality control integrated program during all stages of production (Marcos-Filho, 2015).

Genetic characteristics and environmental effects during the development, harvesting, processing and storage stages are key factors in seed viability period, which is extremely variable. In seeds submitted to unfavorable conditions in any of these stages there may be physiological damage and can hinder the seeds quality and the intensity of such damage is variable with genetic factors and intrinsic to each cultivar (Gris et al., 2010).

Soybean seeds have a high susceptibility to environmental stresses, especially the occurrence of heavy rains, temperature fluctuations and relative humidity at pre-harvest; which are climatic conditions that may result on weathering damage (Cunha et al., 2009; Terasawa et al., 2009). Such damage results from oscillations in humidity due to rain, fog and dew, mainly when associated with high air temperatures cause successive hydration and dehydration of the seeds, being this effect mainly observed in the tegument.

Another deterioration factor related to the physiological and sanitary quality of soybean seeds, which also leads to a loss of yield are phytophagous stinkbug damage. This is one of the most significant groups of insect-plagues in soybean cultivation, feeding directly from the pods and affecting seeds (Depieri and Panizzi, 2011; Silva et al., 2012). Finally, equally important as those factors cited above, mechanical damage causes serious harm to the quality of the soybean seed. The soybean seed is susceptible to the mechanical damages that occur during the harvest, drying and processing, which may negatively influence seed viability and vigor during the storage (Maryam and Oskouie, 2011).
The use of soybean seed with high standards of physical, genetic, physiological and sanitary quality has been the great difference in the successful establishment of the crop at the field (Silva et al., 2011). It is unquestionable the importance of seed processing for the efficiency of the production process. However, due to the morphological arrangement of soybean seeds, which provides little protection to the embryonic axis, since it is located on a tegument that is not much thick (Lopes et al., 2011), the seeds become more susceptible to the mechanical damage which is considered one important cause of seed quality decrease. Therefore, the objective of this study was to evaluate the effect of processing on the physical and physiological qualities of soybean seed lots, before and after each equipment and transport step, during the process flow in a Seed Processing Plant (SPP).

\section{Material and Methods}

The experiment was carried out during the 2009/2010 harvest season and seed samples were collected during soybean seed processing in the months of February and March 2010, conducted in the SPP of Cocari - Cooperativa Agropecuária e Industrial - in Faxinal, in the state of Paraná, Brazil, located at an altitude of $840 \mathrm{~m}$, latitude $24^{\circ} 00^{\prime} 01^{\prime \prime} \mathrm{S}$ and longitude $51^{\circ} 19^{\prime} 10^{\prime \prime} \mathrm{W}$.

The seeds utilized were from early or semi-early cultivars: BRS 232, BRS 282, CD 202, NK 7059 RR, BMX Potência RR and FT Campo Mourão RR. All seeds were mechanically harvested by differents combines. The sampling was done during the processing flow of an amount of seeds from each soybean cultivar for each one of the processing machines. Seed samples were taken before and after each machine (Figure 1), starting with a dry lot of seeds from each cultivar stored in an aerated silo. The treatments consisted of 15 sampling sites total, so that at each sampling site 10 replications of $1.0 \mathrm{~kg}$ of seeds each were collected, within an interval of one minute between the collection of each replication, totaling 150 samples packed in multi-layered paper bags. The sampling sites were selected in order to coincide with the inlet and outlet of each seed lift between one processing equipment and another, in order to evaluate if the equipment could cause some kind of damage to the seeds. The samples were tested at the Quality Control Laboratory of Cocari in Faxinal, Paraná, and at the Seed Technology Laboratory of Embrapa Soja Research Center, in Londrina, Paraná.

\section{Analyzed Characteristics}

The physiological quality of seed was evaluated by the following methods described below: 


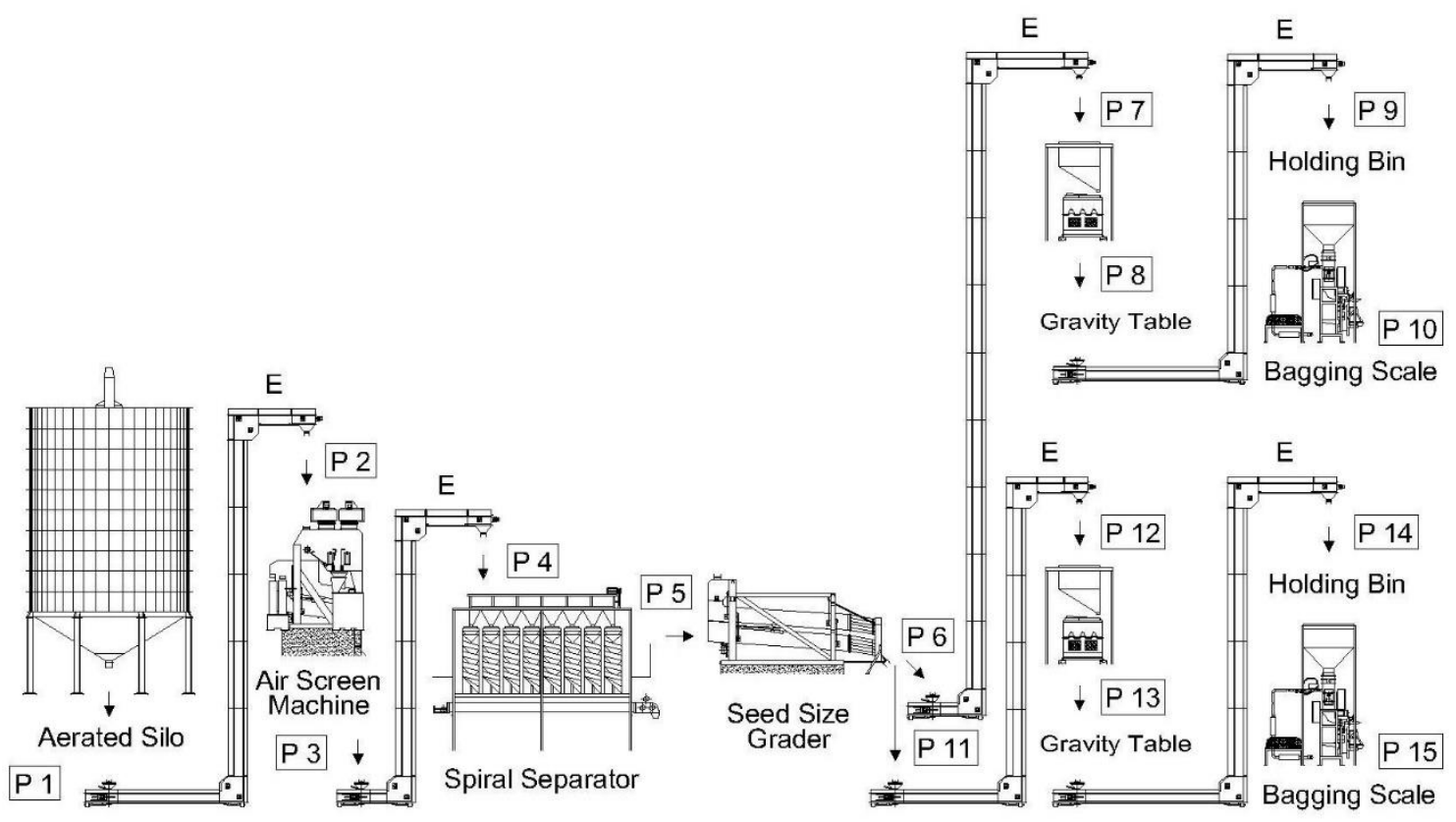

\begin{tabular}{cl}
\hline Sampling sites & \multicolumn{1}{c}{ Stages of soybean seed processing } \\
\hline P 1 & Aerated silo (Silomax brand, model SVR-5366) \\
P 2 & Air Screen machine inlet (Silomax brand, model MLSX-30) \\
P 3 & Air Screen machine outlet \\
P 4 & Spiral separator inlet (Rota brand, model Rota II) \\
P 5 & Spiral separator outlet / Seed size grader inlet \\
P 6 & Seed size grader outlet 6.5 mm (Silomax brand, model SXP-4X4) \\
P 7 & Gravity table inlet $6.5 \mathrm{~mm}$ size (Silomax brand, model SDS-80) \\
P 8 & Gravity table outlet $6.5 \mathrm{~mm}$ size \\
P 9 & Holding bin $6.5 \mathrm{~mm}$ size \\
P 10 & Bagging scale $6.5 \mathrm{~mm}$ size \\
\hline P 11 & Seed size grader outlet 5.5 mm \\
P 12 & Gravity table inlet 5.5 mm size \\
P 13 & Gravity table outlet 5.5 mm size \\
P 14 & Holding bin 5.5 mm size \\
P 15 & Bagging scale 5.5 mm size \\
\hline E & Lift chain (Silomax brand, model SXE-10 Flex Max) \\
\hline
\end{tabular}

Figure 1. Sampling sites scheme for each stage of soybean seed processing at the Seed Processing Plant of Cocari. Faxinal, State of Paraná, 2010.

Germination test: the germination was carried out with eight subsamples of 50 seeds for each treatment and replication, totaling 1,200 subsamples. The seeds were set to germinate between three "Germitest" paper towels moistened with distilled water 2.5 times the weight of the paper. Then rolls of paper were prepared containing the subsamples of seeds and taken to a Mangelsdorf germinator regulated to maintain a constant temperature of $25 \pm 1^{\circ} \mathrm{C}$. The percentage of normal seedlings was evaluated on the eighth day after the beginning of the test, according to criteria established by the
Rules for Seed Testing (Brasil, 2009).

Accelerated aging: was conducted in plastic "gerbox" boxes, containing $40 \mathrm{~mL}$ of water at the bottom and a uniform layer of seeds arranged on top of the surface of the internal screen, maintained in an incubator at $41{ }^{\circ} \mathrm{C}$ for $48 \mathrm{~h}$ (Krzyzanowski et al., 1991). The incubator used was a water jacket incubator, model 3015 from the brand VWR/USA. After the aging period, four subsamples of 50 seeds per treatment and replication were submitted to the germination test. The evaluation was carried out on the fifth day after 
sowing, calculating the seedlings considered normal. The results were expressed in percentages.

Tetrazolium test: was conducted with two subsamples of 50 seeds per treatment and replication, pre-conditioned on "Germitest" paper moistened with distilled water for a period of $16 \mathrm{~h}$, in a germinator with the temperature adjusted to $25{ }^{\circ} \mathrm{C}$. After this period, the seeds were transferred to plastic cups with a volume of $50 \mathrm{~mL}$, totally submersed in a tetrazolium solution (2-3-5, triphenyl tetrazolium chloride) at a concentration of $0.075 \%$, and maintained at a temperature of $40{ }^{\circ} \mathrm{C}$ for approximately 150 minutes in the interior of a germination chamber in the absence of light. After the coloration process, the seeds were washed with running water and maintained submerged until the moment of evaluation in a cooler. Afterwards, the seeds were evaluated individually, sectioned longitudinally and symmetrically with the use of a scalpel blade, and classified in accordance with the criteria proposed by França-Neto et al. (1998). The viability was represented by the sum of the percentages of seeds belonging to classes 1 to 5 , and the level of vigor was represented by classes 1 to 3 . The sum of one type of damage in classes 2 to 8 indicates the total of damages that the seed suffered and the sum of damages in classes 6 to 8 indicates the loss of viability due to that damage. The sum of the damages in class 3 presents seeds found at the last level of high vigor. In all cases, the causes of loss of physiological quality of the seeds were characterized: mechanical damages (classes 2 to 8 ); weathering damage (class 3); and stinkbug damages (classes 2 to 8 ). The potentials for vigor, viability and other types of damages were expressed in percentages.

\section{Experimental design and statistical analysis}

The design utilized was entirely randomized, in a $15 \times 6$ factorial scheme of 15 processing sites and 6 cultivars, with 10 replications. The size of the experimental unit was $1.0 \mathrm{~kg}$ of seeds packed in multi-layered paper bags.

The data obtained were submitted to individual variance analysis and the necessary post-analyses were carried out. The means were submitted to the Scott-Knott grouping test (Scott and Knott, 1974), at a 5\% probability level. The statistical analyses were carried out with the Sisvar statistical analysis program (Ferreira, 2011).

\section{Results and Discussion}

The results of the germination test (Table 1) and of viability and vigor on the tetrazolium test (Tables 2 and 3), displayed improvement in the indexes of these tests for all cultivars throughout processing. For BRS 282 cultivar, germination percentage did not show improvement, due to the fact that physiological quality of this cultivar was maintained at the same initial level, considered elevated (92,7\%) at the time (Table 1).

For all the analyzed cultivars (Table 1), the increase in the germination was enhanced during the entire process of seed processing, although a significant and constant improvement began to be displayed after the seeds passed through the gravity tables for both grading sizes. There was a slight variation in results after leaving the gravity table, since the samples were taken in a continuous flow from a box in which there were seeds originating from different processing times, which could interfere significantly in the seed sample results.

The analysis of the results of seed viability from the tetrazolium test (Table 2) indicated an increase in the values of the cultivars studied throughout processing, except for the BMX Potência RR cultivar. For all the rest, the viability results indicated that the processing sequence contributed positively to the improvement of desirable characteristics of a high quality seed.

The results of the vigor potential of the seeds from the tetrazolium test (Table 3) improved for all cultivars during the processing, with variations in the moment at which such improvement occurred. The cultivar CD 202, $6.5 \mathrm{~mm}$ size, presented an increase in the vigor of the seeds after passing through the spiral machine. This result coincides with the reduction of stinkbug damages (TZ 2 to 8 ) at this point of sampling (Table 6), indicating an improvement at this moment due to the level reduction of stinkbugs damages, which will be presented later. Hesse and Peske (1981), working with soybeans, also verified that the use of the spiral separator improved the physiological quality of the seeds tested. There was an increase in the vigor of the seeds of cultivars BRS 232 and NK 7059 RR for both sizes, for FT Campo Mourão RR through the $6.5 \mathrm{~mm}$ size, and BMX Potência RR through the $5.5 \mathrm{~mm}$ size, after the seeds passed through the seed size grader, and for the rest of the cultivars after passing through the gravity tables. This demonstrates the importance of diverse equipment for improving the physical and physiological quality of the seeds.

The accelerated aging test (Table 4) was less sensitive for identifying improvements in the physiological quality of the seeds during the processing flow. This test indicated that the amount of seeds, in the first stages of processing (silo, entrance and exit of the air screen machine), is more heterogeneous. Light oscillations that were found in the results of the physiological quality of the seeds during the processing could come from the effect of sampling in continuous flow. A similar situation was found by Ferreira and Sá (2010) in corn seeds and Neves et al. (2016) at a soybean SPP, in which 
Table 1. Mean percent for germination of seeds of six different soybean cultivars obtained from samples collected at 15 different sampling sites within the standard processing chain and assessed by the standard germination test.

\begin{tabular}{|c|c|c|c|c|c|c|}
\hline \multirow{3}{*}{ Sampling sites } & \multicolumn{6}{|c|}{ Germination Percent } \\
\hline & \multicolumn{6}{|c|}{ Cultivars } \\
\hline & BRS 232 & BRS 282 & CD 202 & $\begin{array}{c}\text { FT Campo } \\
\text { Mourão RR }\end{array}$ & NK 7059 RR & BMX Potência RR \\
\hline Aerated silo & $84.7 \mathrm{cC}$ & $92.7 \mathrm{aA}$ & $84.2 \mathrm{cD}$ & $88.0 \mathrm{bD}$ & $73.7 \mathrm{eE}$ & $78.1 \mathrm{dE}$ \\
\hline Air screen machine inlet & $84.8 \mathrm{cC}$ & $91.4 \mathrm{aB}$ & $84.7 \mathrm{cD}$ & $88.1 \mathrm{bD}$ & $77.9 \mathrm{dD}$ & $82.8 \mathrm{cD}$ \\
\hline Air screen machine outlet & $85.5 \mathrm{cC}$ & $90.2 \mathrm{aB}$ & $88.1 \mathrm{bC}$ & $90.8 \mathrm{aC}$ & $83.3 \mathrm{dC}$ & $83.3 \mathrm{dD}$ \\
\hline Spiral separator inlet & $88.4 \mathrm{bB}$ & $89.0 \mathrm{bB}$ & $87.4 \mathrm{bC}$ & $91.3 \mathrm{aC}$ & $87.8 \mathrm{bA}$ & $84.8 \mathrm{cC}$ \\
\hline \multirow[t]{2}{*}{ Spiral separator outlet } & $86.9 \mathrm{bC}$ & $91.1 \mathrm{aB}$ & $85.7 \mathrm{bD}$ & $89.4 \mathrm{aD}$ & $85.9 \mathrm{bB}$ & $86.1 \mathrm{bC}$ \\
\hline & \multicolumn{6}{|c|}{ Seed size (grader inlet perfuration) $6.5 \mathrm{~mm}$} \\
\hline Seed Size grader outlet & $84.3 \mathrm{cC}$ & $90.8 \mathrm{aB}$ & $88.8 \mathrm{bB}$ & $92.2 \mathrm{aA}$ & $86.8 \mathrm{bA}$ & $87.8 \mathrm{bB}$ \\
\hline Gravity table inlet & $85.2 \mathrm{cC}$ & $91.9 \mathrm{aB}$ & $88.9 \mathrm{bC}$ & $88.1 \mathrm{bD}$ & $83.6 \mathrm{cC}$ & $88.5 \mathrm{bB}$ \\
\hline Gravity table outlet & $92.5 \mathrm{aA}$ & $93.3 \mathrm{aA}$ & $93.8 \mathrm{aA}$ & $91.5 \mathrm{bC}$ & $85.6 \mathrm{cB}$ & $90.2 \mathrm{bA}$ \\
\hline Holding bin & $91.1 \mathrm{bA}$ & $93.6 \mathrm{aA}$ & $94.6 \mathrm{aA}$ & $94.5 \mathrm{aA}$ & $87.6 \mathrm{cA}$ & $90.9 \mathrm{bA}$ \\
\hline \multirow[t]{2}{*}{ Bagging scale } & $90.8 \mathrm{bA}$ & $90.6 \mathrm{bB}$ & $92.0 \mathrm{bB}$ & $95.0 \mathrm{aA}$ & $87.4 \mathrm{cA}$ & $92.1 \mathrm{bA}$ \\
\hline & \multicolumn{6}{|c|}{ Seed size (grader inlet perfuration) $5.5 \mathrm{~mm}$} \\
\hline Seed Size grader outlet & $85.1 \mathrm{bC}$ & $91.3 \mathrm{aB}$ & $87.3 \mathrm{bC}$ & $91.5 \mathrm{aC}$ & $85.3 \mathrm{bB}$ & $89.6 \mathrm{aB}$ \\
\hline Gravity table inlet & $85.0 \mathrm{cC}$ & $92.6 \mathrm{aA}$ & $91.4 \mathrm{aB}$ & $89.7 \mathrm{bD}$ & $83.1 \mathrm{cC}$ & $89.0 \mathrm{bB}$ \\
\hline Gravity table outlet & $88.4 \mathrm{cB}$ & $95.4 \mathrm{aA}$ & $95.2 \mathrm{aA}$ & $96.3 \mathrm{aA}$ & $87.7 \mathrm{cA}$ & $90.8 \mathrm{bA}$ \\
\hline Holding bin & $90.2 \mathrm{bA}$ & $93.9 \mathrm{aA}$ & $94.2 \mathrm{aA}$ & $94.2 \mathrm{aA}$ & $88.2 \mathrm{cA}$ & $90.6 \mathrm{bA}$ \\
\hline Bagging scale & $88.8 \mathrm{bB}$ & $90.8 \mathrm{bB}$ & $92.4 \mathrm{aB}$ & $92.8 \mathrm{aB}$ & $90.1 \mathrm{bA}$ & $91.9 \mathrm{aA}$ \\
\hline CV (\%) & 2.72 & & & & & \\
\hline General mean & 88.92 & & & & & \\
\hline
\end{tabular}

Means followed by the same small letter in the same row and the same capital letter in the same column for each response variable are not statistically different between each other by the Scott-Knott test at $5 \%$ probability.

Table 2. Mean percent for viability of seeds of six different soybean cultivars obtained from samples collected at 15 different sampling sites within the standard processing chain and assessed by the tetrazolium test (TZ 1-5).

\begin{tabular}{|c|c|c|c|c|c|c|}
\hline \multirow{3}{*}{ Sampling sites } & \multicolumn{6}{|c|}{ Viability Percent } \\
\hline & \multicolumn{6}{|c|}{ Cultivars } \\
\hline & BRS 232 & BRS 282 & CD 202 & $\begin{array}{c}\text { FT Campo } \\
\text { Mourão RR }\end{array}$ & NK 7059 RR & BMX Potência RR \\
\hline Aerated silo & $86.6 \mathrm{bB}$ & $92.3 \mathrm{aB}$ & $90.5 \mathrm{aB}$ & $84.5 \mathrm{bC}$ & $80.0 \mathrm{cC}$ & $85.8 \mathrm{bB}$ \\
\hline Air screen machine inlet & $86.1 \mathrm{cB}$ & $93.2 \mathrm{aB}$ & $88.1 \mathrm{bB}$ & $83.8 \mathrm{cC}$ & $81.7 \mathrm{cC}$ & $83.8 \mathrm{cB}$ \\
\hline Air screen machine outlet & $85.6 \mathrm{bB}$ & $92.0 \mathrm{aB}$ & $89.5 \mathrm{aB}$ & $86.6 \mathrm{bC}$ & $85.5 \mathrm{bB}$ & $85.1 \mathrm{bB}$ \\
\hline Spiral separator inlet & $82.9 \mathrm{bB}$ & $90.7 \mathrm{aB}$ & $89.7 \mathrm{aB}$ & $86.1 \mathrm{bC}$ & $83.4 \mathrm{bC}$ & $85.4 \mathrm{bB}$ \\
\hline \multirow[t]{2}{*}{ Spiral separator outlet } & $86.3 \mathrm{bB}$ & $91.1 \mathrm{aB}$ & $89.6 \mathrm{aB}$ & $89.2 \mathrm{aB}$ & $82.7 \mathrm{bC}$ & $85.7 \mathrm{bB}$ \\
\hline & \multicolumn{6}{|c|}{ Seed size (grader inlet perfuration) $6.5 \mathrm{~mm}$} \\
\hline Seed Size grader outlet & $86.4 \mathrm{bB}$ & $92.7 \mathrm{aB}$ & $92.6 \mathrm{aA}$ & $88.6 \mathrm{bB}$ & $86.2 \mathrm{bB}$ & $85.6 \mathrm{bB}$ \\
\hline Gravity table inlet & $88.7 \mathrm{bB}$ & $93.0 \mathrm{aB}$ & $92.6 \mathrm{aA}$ & $88.5 \mathrm{bB}$ & $85.1 \mathrm{cB}$ & $85.2 \mathrm{cB}$ \\
\hline Gravity table outlet & $93.4 \mathrm{aA}$ & $95.8 \mathrm{aA}$ & $94.4 \mathrm{aA}$ & $91.9 \mathrm{bA}$ & $85.7 \mathrm{cB}$ & $90.7 \mathrm{bA}$ \\
\hline Holding bin & $90.4 \mathrm{bA}$ & $94.7 \mathrm{aA}$ & $94.2 \mathrm{aA}$ & $90.0 \mathrm{bB}$ & $86.6 \mathrm{cB}$ & $87.4 \mathrm{cB}$ \\
\hline \multirow[t]{2}{*}{ Bagging scale } & $92.0 \mathrm{bA}$ & $95.9 \mathrm{aA}$ & $92.4 \mathrm{bA}$ & $91.5 \mathrm{bA}$ & $89.4 \mathrm{cA}$ & $86.6 \mathrm{cB}$ \\
\hline & \multicolumn{6}{|c|}{ Seed size (grader inlet perfuration) $5.5 \mathrm{~mm}$} \\
\hline Seed Size grader outlet & $86.2 \mathrm{bB}$ & $93.6 \mathrm{aB}$ & $91.3 \mathrm{aB}$ & $86.8 \mathrm{bC}$ & $84.6 \mathrm{bC}$ & $87.0 \mathrm{bB}$ \\
\hline Gravity table inlet & $88.5 \mathrm{bB}$ & $93.8 \mathrm{aB}$ & $93.8 \mathrm{aA}$ & $90.6 \mathrm{aB}$ & $86.3 \mathrm{bB}$ & $87.2 \mathrm{bB}$ \\
\hline Gravity table outlet & $92.6 \mathrm{bA}$ & $96.5 \mathrm{aA}$ & $92.7 \mathrm{bA}$ & $92.2 \mathrm{bA}$ & $88.0 \mathrm{cA}$ & $90.0 \mathrm{cA}$ \\
\hline Holding bin & $91.3 \mathrm{bA}$ & $95.6 \mathrm{aA}$ & $95.2 \mathrm{aA}$ & $92.4 \mathrm{bA}$ & $89.2 \mathrm{bA}$ & $89.8 \mathrm{bA}$ \\
\hline Bagging scale & $91.3 \mathrm{bA}$ & $94.5 \mathrm{aA}$ & $93.5 \mathrm{aA}$ & $93.2 \mathrm{aA}$ & $90.9 \mathrm{bA}$ & $87.7 \mathrm{cB}$ \\
\hline CV (\%) & 4.20 & & & & & \\
\hline General mean & 89.31 & & & & & \\
\hline
\end{tabular}

Means followed by the same small letter in the same row and the same capital letter in the same column for each response variable are not statistically different between each other by the Scott-Knott test at 5\% probability. 
Table 3. Mean percent for vigor of seeds of six different soybean cultivars obtained from samples collected at 15 different sampling sites within the standard processing chain and assessed by the tetrazolium test (TZ 1-3).

\begin{tabular}{|c|c|c|c|c|c|c|}
\hline \multirow{3}{*}{ Sampling sites } & \multicolumn{6}{|c|}{ Vigor Percent } \\
\hline & \multicolumn{6}{|c|}{ Cultivars } \\
\hline & BRS 232 & BRS 282 & CD 202 & $\begin{array}{c}\text { FT Campo } \\
\text { Mourão RR }\end{array}$ & $\begin{array}{c}\text { NK } 7059 \\
\text { RR }\end{array}$ & $\begin{array}{c}\text { BMX Potência } \\
\text { RR }\end{array}$ \\
\hline Aerated silo & $58.6 \mathrm{cB}$ & $78.9 \mathrm{aB}$ & $71.8 \mathrm{bB}$ & $63.1 \mathrm{cC}$ & $47.1 \mathrm{dC}$ & $69.9 \mathrm{bB}$ \\
\hline Air screen machine inlet & $58.0 \mathrm{~dB}$ & $78.6 \mathrm{aB}$ & $67.5 \mathrm{bB}$ & $64.0 \mathrm{cC}$ & $56.2 \mathrm{~dB}$ & $68.1 \mathrm{bB}$ \\
\hline Air screen machine outlet & $59.3 \mathrm{cB}$ & $77.5 \mathrm{aB}$ & $70.1 \mathrm{bB}$ & $68.5 \mathrm{bB}$ & $61.3 \mathrm{cA}$ & $69.6 \mathrm{bB}$ \\
\hline Spiral separator inlet & $58.7 \mathrm{cB}$ & $76.9 \mathrm{aB}$ & $70.6 \mathrm{bB}$ & $68.2 \mathrm{bB}$ & $57.2 \mathrm{cB}$ & $67.9 \mathrm{bB}$ \\
\hline \multirow[t]{2}{*}{ Spiral separator outlet } & $59.7 \mathrm{cB}$ & $78.3 \mathrm{aB}$ & $73.7 \mathrm{aA}$ & $68.9 \mathrm{bB}$ & $54.9 \mathrm{cB}$ & $70.0 \mathrm{bB}$ \\
\hline & \multicolumn{6}{|c|}{ Seed size (grader inlet perfuration) $6.5 \mathrm{~mm}$} \\
\hline Seed Size grader outlet & $59.8 \mathrm{cB}$ & $79.7 \mathrm{aB}$ & $76.1 \mathrm{aA}$ & $70.6 \mathrm{bA}$ & $58.6 \mathrm{cB}$ & $69.3 \mathrm{bB}$ \\
\hline Gravity table inlet & $65.3 \mathrm{cA}$ & $80.1 \mathrm{aB}$ & $73.8 \mathrm{bA}$ & $70.7 \mathrm{bA}$ & $61.3 \mathrm{cA}$ & $70.8 \mathrm{bB}$ \\
\hline Gravity table outlet & $71.9 \mathrm{bA}$ & $81.8 \mathrm{aA}$ & $77.6 \mathrm{aA}$ & $75.4 \mathrm{bA}$ & $62.6 \mathrm{cA}$ & $78.3 \mathrm{aA}$ \\
\hline Holding bin & $69.6 \mathrm{cA}$ & $83.2 \mathrm{aA}$ & $76.1 \mathrm{bA}$ & $73.4 \mathrm{bA}$ & $63.5 \mathrm{dA}$ & $74.6 \mathrm{bA}$ \\
\hline \multirow[t]{2}{*}{ Bagging scale } & $68.6 \mathrm{cA}$ & $86.3 \mathrm{aA}$ & $75.4 \mathrm{bA}$ & $74.8 \mathrm{bA}$ & $64.5 \mathrm{cA}$ & $72.4 \mathrm{bB}$ \\
\hline & \multicolumn{6}{|c|}{ Seed size (grader inlet perfuration) $5.5 \mathrm{~mm}$} \\
\hline Seed Size grader outlet & $61.8 \mathrm{cB}$ & $79.0 \mathrm{aB}$ & $71.5 \mathrm{bB}$ & $69.1 \mathrm{bB}$ & $56.5 \mathrm{cB}$ & $70.9 \mathrm{bB}$ \\
\hline Gravity table inlet & $66.6 \mathrm{cA}$ & $79.3 \mathrm{aB}$ & $73.2 \mathrm{bA}$ & $74.0 \mathrm{bA}$ & $59.6 \mathrm{dA}$ & $73.2 \mathrm{bA}$ \\
\hline Gravity table outlet & $70.6 \mathrm{cA}$ & $83.5 \mathrm{aA}$ & $74.4 \mathrm{bA}$ & $73.3 \mathrm{bA}$ & $62.4 \mathrm{dA}$ & $77.5 \mathrm{bA}$ \\
\hline Holding bin & $71.3 \mathrm{cA}$ & $83.8 \mathrm{aA}$ & $75.8 \mathrm{bA}$ & $74.4 \mathrm{bA}$ & $64.5 \mathrm{dA}$ & $76.7 \mathrm{bA}$ \\
\hline Bagging scale & $72.9 \mathrm{bA}$ & $81.9 \mathrm{aA}$ & $75.3 \mathrm{bA}$ & $74.4 \mathrm{bA}$ & $64.3 \mathrm{cA}$ & $75.9 \mathrm{bA}$ \\
\hline CV (\%) & 8.79 & & & & & \\
\hline General mean & 70.30 & & & & & \\
\hline
\end{tabular}

Means followed by the same small letter in the same row and the same capital letter in the same column for each response variable are not statistically different between each other by the Scott-Knott test at $5 \%$ probability.

Table 4. Mean percent for seed accelerated aging germination of six different soybean cultivars obtained from samples collected at 15 different sampling sites within the standard processing chain and assessed by the accelerated aging test.

\begin{tabular}{|c|c|c|c|c|c|c|}
\hline \multirow{3}{*}{ Sampling sites } & \multicolumn{6}{|c|}{ Accelerated Aging Percent } \\
\hline & \multicolumn{6}{|c|}{ Cultivars } \\
\hline & BRS 232 & BRS 282 & CD 202 & $\begin{array}{l}\text { FT Campo } \\
\text { Mourão RR } \\
\end{array}$ & NK 7059 RR & $\begin{array}{c}\text { BMX Potência } \\
\text { RR }\end{array}$ \\
\hline Aerated silo & $58.1 \mathrm{cB}$ & $87.6 \mathrm{aA}$ & $65.8 \mathrm{bC}$ & $86.4 \mathrm{aA}$ & $51.5 \mathrm{dF}$ & $68.6 \mathrm{bA}$ \\
\hline Air screen machine inlet & $56.0 \mathrm{cC}$ & $84.9 \mathrm{aB}$ & $68.3 \mathrm{bB}$ & $85.9 \mathrm{aA}$ & $67.2 \mathrm{bE}$ & $67.4 \mathrm{bA}$ \\
\hline Air screen machine outlet & $57.2 \mathrm{~dB}$ & $87.2 \mathrm{aA}$ & $61.8 \mathrm{cD}$ & $86.5 \mathrm{aA}$ & $76.7 \mathrm{bB}$ & $63.2 \mathrm{cB}$ \\
\hline Spiral separator inlet & $61.0 \mathrm{eA}$ & $88.0 \mathrm{aA}$ & $65.9 \mathrm{dC}$ & $84.8 \mathrm{bA}$ & $81.7 \mathrm{cA}$ & $68.3 \mathrm{dA}$ \\
\hline \multirow[t]{2}{*}{ Spiral separator outlet } & $59.9 \mathrm{dA}$ & $88.9 \mathrm{aA}$ & $65.7 \mathrm{cC}$ & $86.6 \mathrm{aA}$ & $77.9 \mathrm{bB}$ & $67.6 \mathrm{cA}$ \\
\hline & \multicolumn{6}{|c|}{ Seed size (grader inlet perfuration) $6.5 \mathrm{~mm}$} \\
\hline Seed Size grader outlet & $61.3 \mathrm{dA}$ & $88.5 \mathrm{aA}$ & $61.4 \mathrm{dD}$ & $88.0 \mathrm{aA}$ & $70.1 \mathrm{bD}$ & $67.0 \mathrm{cA}$ \\
\hline Gravity table inlet & $60.5 \mathrm{cA}$ & $85.8 \mathrm{aB}$ & $61.3 \mathrm{cD}$ & $87.8 \mathrm{aA}$ & $72.7 \mathrm{bD}$ & $63.2 \mathrm{cB}$ \\
\hline Gravity table outlet & $62.0 \mathrm{dA}$ & $88.1 \mathrm{aA}$ & $62.7 \mathrm{dD}$ & $89.9 \mathrm{aA}$ & $75.0 \mathrm{bC}$ & $67.0 \mathrm{cA}$ \\
\hline Holding bin & $58.2 \mathrm{~dB}$ & $89.0 \mathrm{aA}$ & $68.4 \mathrm{cB}$ & $89.1 \mathrm{aA}$ & $71.8 \mathrm{bD}$ & $67.8 \mathrm{cA}$ \\
\hline \multirow[t]{2}{*}{ Bagging scale } & $58.5 \mathrm{~dB}$ & $83.2 \mathrm{bB}$ & $65.0 \mathrm{dC}$ & $88.6 \mathrm{aA}$ & $72.8 \mathrm{cD}$ & $69.9 \mathrm{cA}$ \\
\hline & \multicolumn{6}{|c|}{ Seed size (grader inlet perfuration) $5.5 \mathrm{~mm}$} \\
\hline Seed Size grader outlet & $53.9 \mathrm{eC}$ & $88.9 \mathrm{aA}$ & $69.1 \mathrm{bB}$ & $87.1 \mathrm{aA}$ & $66.1 \mathrm{cE}$ & $62.7 \mathrm{~dB}$ \\
\hline Gravity table inlet & $59.1 \mathrm{dA}$ & $89.1 \mathrm{aA}$ & $72.6 \mathrm{bA}$ & $86.7 \mathrm{aA}$ & $74.7 \mathrm{bC}$ & $68.9 \mathrm{cA}$ \\
\hline Gravity table outlet & $58.7 \mathrm{~dB}$ & $89.8 \mathrm{aA}$ & $71.6 \mathrm{bA}$ & $88.4 \mathrm{aA}$ & $74.0 \mathrm{bC}$ & $66.4 \mathrm{cA}$ \\
\hline Holding bin & $60.2 \mathrm{eA}$ & 88.9 aA & $74.5 \mathrm{bA}$ & $87.2 \mathrm{aA}$ & $71.2 \mathrm{cD}$ & $66.4 \mathrm{dA}$ \\
\hline Bagging scale & $61.8 \mathrm{eA}$ & $84.1 \mathrm{bB}$ & $72.8 \mathrm{cA}$ & $87.9 \mathrm{aA}$ & $70.7 \mathrm{cD}$ & $67.0 \mathrm{dA}$ \\
\hline CV (\%) & 4.43 & & & & & \\
\hline General mean & 73.24 & & & & & \\
\hline
\end{tabular}

Means followed by the same small letter in the same row and the same capital letter in the same column for each response variable are not statistically different between each other by the Scott-Knott test at $5 \%$ probability. 
the germination of the sampled seeds showed a decrease in the results of samples collected at intermediary sites of processing.

Based on the results observed in Table 5, it can be stated that the mechanical damages to the seeds (TZ 2 to 8 ) were concentrated in the $6.5 \mathrm{~mm}$ size for all the cultivars studied. Among the cultivars, BRS 232 was the one that presented the highest level of mechanical damage on its seeds, in part because of its characteristics of larger seeds and a greater mass of a thousand seeds.

The mechanical damages to the seeds were reduced for the $5.5 \mathrm{~mm}$ sizes of cultivars BRS 232, FT Campo Mourão RR and BMX Potência RR after passing through the gravity table, which indicated a possible increase in quality that this equipment can provide for seed lots. These results coincide with those of Fessel et al. (2003), in which, after corn seeds passed through a gravity table, improvements were found for the following: percentage of germination, first germination count, cold test performance, accelerated aging, and germination speed index.

These results also coincide with those of França-Neto et al. (2006) which, working with clean soybean seeds classified by size, evaluated the density and physiological quality of those seeds after passing through a gravity table (CASP S120). The referenced authors concluded that this equipment contributes effectively to the improvement of the viability and vigor of the seed lots, due to the reduction of indices of mechanical damage. This confirms the importance of the gravity table as a final finishing machine in the soybean seed processing line. Parde et al. (2002), working with the seeds of six soybean cultivars with different initial moisture content in an SPP, found that soybean seeds at $12 \%$ of moisture content suffer less mechanical damage than seeds with lower moisture content. Furthermore, they verified that the air screen machines, seed size grader and the gravity table improved the seeds physiological performance.

At the SPP studied, planned according to the parameters of seed technology, there was no increase in mechanical damage along the processing line, which indicates that the equipment, lifts and other transport systems at this facility did not cause additional mechanical damage to the seeds.

Different results were found by Juvino et al. (2014) at a SSP for soybean who found that processing didn't change the seed vigor results. Silva et al. (2011) at a SPP for soybean seed processing verified the increase of mechanical damages during processing due to bucket elevators. Neves et al. (2016)

Table 5. Mean percent for total mechanical damage of six different soybean cultivars obtained from samples collected at 15 different sampling sites within the standard processing chain and assessed by the tetrazolium test (TZ 2-8).

\begin{tabular}{|c|c|c|c|c|c|c|}
\hline \multirow{3}{*}{ Sampling sites } & \multicolumn{6}{|c|}{ Total Mechanical Damage Percent } \\
\hline & \multicolumn{6}{|c|}{ Cultivars } \\
\hline & BRS 232 & BRS 282 & CD 202 & $\begin{array}{l}\text { FT Campo } \\
\text { Mourão RR }\end{array}$ & NK 7059 RR & $\begin{array}{c}\text { BMX Potência } \\
\text { RR }\end{array}$ \\
\hline Aerated silo & $30.0 \mathrm{aB}$ & $16.5 \mathrm{cA}$ & $12.5 \mathrm{~dB}$ & $21.9 \mathrm{bB}$ & $23.3 \mathrm{bA}$ & $18.1 \mathrm{cB}$ \\
\hline Air screen machine inlet & $33.9 \mathrm{aA}$ & $13.3 \mathrm{cA}$ & $15.3 \mathrm{cA}$ & $21.4 \mathrm{bB}$ & $18.2 \mathrm{bB}$ & $22.4 \mathrm{bA}$ \\
\hline Air screen machine outlet & $31.5 \mathrm{aB}$ & $15.1 \mathrm{cA}$ & $12.3 \mathrm{cB}$ & $19.7 \mathrm{bB}$ & $14.8 \mathrm{cB}$ & $18.0 \mathrm{bB}$ \\
\hline Spiral separator inlet & $30.5 \mathrm{aB}$ & $14.5 \mathrm{cA}$ & $16.1 \mathrm{cA}$ & $24.5 \mathrm{bA}$ & $15.5 \mathrm{cB}$ & $16.8 \mathrm{cB}$ \\
\hline \multirow[t]{2}{*}{ Spiral separator outlet } & $33.1 \mathrm{aA}$ & $14.2 \mathrm{cA}$ & $13.9 \mathrm{cB}$ & $22.3 \mathrm{bB}$ & $16.6 \mathrm{cB}$ & $19.3 \mathrm{bB}$ \\
\hline & \multicolumn{6}{|c|}{ Seed size (grader inlet perfuration) $6.5 \mathrm{~mm}$} \\
\hline Seed Size grader outlet & $33.8 \mathrm{aA}$ & $14.8 \mathrm{dA}$ & $18.1 \mathrm{cA}$ & $25.3 \mathrm{bA}$ & $18.9 \mathrm{cB}$ & $21.4 \mathrm{cA}$ \\
\hline Gravity table inlet & $35.5 \mathrm{aA}$ & $14.7 \mathrm{cA}$ & $17.8 \mathrm{cA}$ & $22.0 \mathrm{bB}$ & $20.0 \mathrm{bA}$ & $21.7 \mathrm{bA}$ \\
\hline Gravity table outlet & $29.1 \mathrm{aB}$ & $11.7 \mathrm{dA}$ & $17.7 \mathrm{cA}$ & $24.6 \mathrm{bA}$ & $18.1 \mathrm{cB}$ & $18.5 \mathrm{cB}$ \\
\hline Holding bin & $27.3 \mathrm{aC}$ & $15.4 \mathrm{cA}$ & $19.4 \mathrm{cA}$ & $26.0 \mathrm{aA}$ & $22.8 \mathrm{bA}$ & $21.9 \mathrm{bA}$ \\
\hline \multirow[t]{2}{*}{ Bagging scale } & $28.4 \mathrm{aC}$ & $13.7 \mathrm{cA}$ & $15.4 \mathrm{cA}$ & $21.8 \mathrm{bB}$ & $24.9 \mathrm{bA}$ & $23.1 \mathrm{bA}$ \\
\hline & \multicolumn{6}{|c|}{ Seed size (grader inlet perfuration) $5.5 \mathrm{~mm}$} \\
\hline Seed Size grader outlet & $25.0 \mathrm{aC}$ & $13.9 \mathrm{cA}$ & $13.7 \mathrm{cB}$ & $23.4 \mathrm{aA}$ & $15.0 \mathrm{cB}$ & $19.8 \mathrm{bA}$ \\
\hline Gravity table inlet & $25.4 \mathrm{aC}$ & $13.1 \mathrm{cA}$ & $12.0 \mathrm{cB}$ & $20.3 \mathrm{bB}$ & $22.3 \mathrm{bA}$ & $20.4 \mathrm{bA}$ \\
\hline Gravity table outlet & $22.1 \mathrm{aD}$ & $11.6 \mathrm{cA}$ & $15.2 \mathrm{cA}$ & $21.6 \mathrm{aB}$ & $18.2 \mathrm{bB}$ & $17.2 \mathrm{bB}$ \\
\hline Holding bin & $25.6 \mathrm{aC}$ & $12.5 \mathrm{cA}$ & $16.1 \mathrm{cA}$ & $21.9 \mathrm{bB}$ & $20.6 \mathrm{bA}$ & $16.8 \mathrm{cB}$ \\
\hline Bagging scale & $22.5 \mathrm{aD}$ & $13.4 \mathrm{bA}$ & $13.2 \mathrm{bB}$ & $20.9 \mathrm{aB}$ & $16.5 \mathrm{bB}$ & $16.1 \mathrm{bB}$ \\
\hline CV (\%) & 23.39 & & & & & \\
\hline General mean & 19.84 & & & & & \\
\hline
\end{tabular}

Means followed by the same small letter in the same row and the same capital letter in the same column for each response variable are not statistically different between each other by the Scott-Knott test at 5\% probability. 
also found cumulative and increasing mechanical damages at a soybean SPP. Fessel et al. (2003) also verified an increase in the percentage of mechanical damage, with an accumulated effect during the processing stages of corn seeds. These results show how seed processing plants having multiple designs and distinct equipment from each other can affect differently soybean and other seeds.

In Table 6, for the cultivars BRS 232, CD 202, FT Campo Mourão RR, and NK 7059 RR, the spiral machine significantly reduced the damages from stinkbugs (TZ 2 to 8 ) in the seeds classified at the $6.5 \mathrm{~mm}$ size. For the BRS 282 cultivar, there was no reduction for this kind of damage, as the stinkbug damage index to the seeds of this cultivar was considered low. Conversely, after the seeds passed through the spiral separator, the stinkbug damages for the $5.5 \mathrm{~mm}$ size were reduced only for the FT Campo Mourão RR cultivar. It remained the same for seeds from the BRS 282 and CD 202 cultivars, and increased for the BRS
232, NK 7059 RR and BMX Potência RR cultivars, which indicates the possible concentration of this type of damage on smaller seeds. In other words, the reduced size of the seeds is induced precisely due to the attack from the pests.

The results of weathering damage (TZ 3) on the seeds, indicated in Table 7, presented no alterations throughout the processing line, with the exception of the BRS 232 cultivar. With this data, it can be inferred that there is not a processing machine that eliminates or decreases this type of damage. Weathering damage is a progressive kind of damage during seed storage (Moreano et al., 2011) and is impossible to correct or reduce (Moreano et al., 2013). The initial indices of weathering damage (TZ 3) found in the seeds were not sufficient to decrease the quality of the seed lots, since these seeds had a good storage condition. Moreano et al. (2011) worked with soybean seeds, with initial weathering damages (TZ 3) similar to those found in this experiment and classified them as of high vigor.

Table 6. Mean percent for total stinkbug damage of six different soybean cultivars obtained from samples collected at 15 different sampling sites within the standard processing chain and assessed by the tetrazolium test (TZ 2-8).

\begin{tabular}{|c|c|c|c|c|c|c|}
\hline \multirow{3}{*}{ Sampling sites } & \multicolumn{6}{|c|}{ Total Stinkbug Damage Percent } \\
\hline & \multicolumn{6}{|c|}{ Cultivars } \\
\hline & BRS 232 & BRS 282 & CD 202 & $\begin{array}{l}\text { FT Campo } \\
\text { Mourão RR }\end{array}$ & NK 7059 RR & $\begin{array}{c}\text { BMX Potência } \\
\text { RR }\end{array}$ \\
\hline Aerated silo & $15.6 \mathrm{bA}$ & $6.0 \mathrm{cA}$ & $23.2 \mathrm{aA}$ & $21.9 \mathrm{aA}$ & $25.2 \mathrm{aB}$ & $15.2 \mathrm{bB}$ \\
\hline Air screen machine inlet & $14.3 \mathrm{cB}$ & $9.0 \mathrm{dA}$ & $21.6 \mathrm{bA}$ & $19.1 \mathrm{bA}$ & $25.5 \mathrm{aB}$ & $15.3 \mathrm{cB}$ \\
\hline Air screen machine outlet & $14.8 \mathrm{cA}$ & $6.4 \mathrm{dA}$ & $20.9 \mathrm{bA}$ & $22.5 \mathrm{aA}$ & $25.2 \mathrm{aB}$ & $19.1 \mathrm{bA}$ \\
\hline Spiral separator inlet & $15.1 \mathrm{bA}$ & $8.1 \mathrm{cA}$ & $18.1 \mathrm{bA}$ & $17.0 \mathrm{bB}$ & $25.1 \mathrm{aB}$ & $17.8 \mathrm{bA}$ \\
\hline \multirow[t]{2}{*}{ Spiral separator outlet } & $13.8 \mathrm{cB}$ & $7.8 \mathrm{dA}$ & $20.0 \mathrm{bA}$ & $14.9 \mathrm{cB}$ & $25.4 \mathrm{aB}$ & $18.5 \mathrm{bA}$ \\
\hline & \multicolumn{6}{|c|}{ Seed size (grader inlet perfuration) $6.5 \mathrm{~mm}$} \\
\hline Seed Size grader outlet & $14.2 \mathrm{bB}$ & $6.7 \mathrm{cA}$ & $16.3 \mathrm{bB}$ & $16.4 \mathrm{bB}$ & $22.5 \mathrm{aC}$ & $15.6 \mathrm{bB}$ \\
\hline Gravity table inlet & $12.3 \mathrm{bB}$ & $6.0 \mathrm{cA}$ & $14.6 \mathrm{bB}$ & $15.0 \mathrm{bB}$ & $19.2 \mathrm{aC}$ & $15.4 \mathrm{bB}$ \\
\hline Gravity table outlet & $9.9 \mathrm{cB}$ & $7.8 \mathrm{cA}$ & $13.5 \mathrm{bB}$ & $12.6 \mathrm{bB}$ & $19.7 \mathrm{aC}$ & $13.2 \mathrm{bB}$ \\
\hline Holding bin & $13.7 \mathrm{bB}$ & $6.4 \mathrm{cA}$ & $16.0 \mathrm{bB}$ & $14.5 \mathrm{bB}$ & $19.4 \mathrm{aC}$ & $12.1 \mathrm{bB}$ \\
\hline \multirow[t]{2}{*}{ Bagging scale } & $13.8 \mathrm{bB}$ & $5.1 \mathrm{cA}$ & $14.4 \mathrm{bB}$ & $14.2 \mathrm{bB}$ & $19.5 \mathrm{aC}$ & $14.3 \mathrm{bB}$ \\
\hline & \multicolumn{6}{|c|}{ Seed size (grader inlet perfuration) $5.5 \mathrm{~mm}$} \\
\hline Seed Size grader outlet & $20.3 \mathrm{bA}$ & $7.1 \mathrm{cA}$ & $20.0 \mathrm{bA}$ & $18.5 \mathrm{bA}$ & $30.7 \mathrm{aA}$ & $20.7 \mathrm{bA}$ \\
\hline Gravity table inlet & $16.4 \mathrm{aA}$ & $7.4 \mathrm{bA}$ & $18.2 \mathrm{aA}$ & $15.7 \mathrm{aB}$ & $19.3 \mathrm{aC}$ & $17.1 \mathrm{aA}$ \\
\hline Gravity table outlet & $16.4 \mathrm{bA}$ & $7.4 \mathrm{cA}$ & $15.6 \mathrm{bB}$ & $16.8 \mathrm{bB}$ & $26.0 \mathrm{aB}$ & $18.3 \mathrm{bA}$ \\
\hline Holding bin & $15.2 \mathrm{bA}$ & $6.2 \mathrm{cA}$ & $14.8 \mathrm{bB}$ & $17.6 \mathrm{bB}$ & $27.5 \mathrm{aB}$ & $18.1 \mathrm{bA}$ \\
\hline Bagging scale & $16.0 \mathrm{bA}$ & $7.5 \mathrm{cA}$ & $17.9 \mathrm{bA}$ & $16.8 \mathrm{bB}$ & $29.2 \mathrm{aA}$ & $17.7 \mathrm{bA}$ \\
\hline $\mathrm{CV}(\%)$ & 26.65 & & & & & \\
\hline General mean & 16.15 & & & & & \\
\hline
\end{tabular}

Means followed by the same small letter in the same row and the same capital letter in the same column for each response variable are not statistically different between each other by the Scott-Knott test at $5 \%$ probability. 
Table 7. Mean percent for weathering damage of six different soybean cultivars obtained from samples collected at 15 different sampling sites within the standard processing chain and assessed by the tetrazolium test (TZ 3).

\begin{tabular}{|c|c|c|c|c|c|c|}
\hline \multirow{3}{*}{ Sampling sites } & \multicolumn{6}{|c|}{ Weathering Damage Percent } \\
\hline & \multicolumn{6}{|c|}{ Cultivars } \\
\hline & BRS 232 & BRS 282 & CD 202 & $\begin{array}{l}\text { FT Campo } \\
\text { Mourão RR }\end{array}$ & NK 7059 RR & $\begin{array}{c}\text { BMX Potência } \\
\text { RR }\end{array}$ \\
\hline Aerated silo & $30.3 \mathrm{bA}$ & $37.2 \mathrm{aA}$ & $34.3 \mathrm{aA}$ & $31.4 \mathrm{bA}$ & $26.9 \mathrm{cA}$ & $31.9 \mathrm{bA}$ \\
\hline Air screen machine inlet & $30.2 \mathrm{bA}$ & $36.2 \mathrm{aA}$ & $32.7 \mathrm{aA}$ & $34.5 \mathrm{aA}$ & $28.2 \mathrm{bA}$ & $30.8 \mathrm{bA}$ \\
\hline Air screen machine outlet & $26.9 \mathrm{bB}$ & $36.3 \mathrm{aA}$ & $33.8 \mathrm{aA}$ & $32.8 \mathrm{aA}$ & $29.8 \mathrm{bA}$ & $32.3 \mathrm{aA}$ \\
\hline Spiral separator inlet & $29.6 \mathrm{bA}$ & $36.3 \mathrm{aA}$ & $35.0 \mathrm{aA}$ & $31.8 \mathrm{bA}$ & $29.7 \mathrm{bA}$ & $30.4 \mathrm{bA}$ \\
\hline \multirow[t]{2}{*}{ Spiral separator outlet } & $33.2 \mathrm{bA}$ & $36.8 \mathrm{aA}$ & $33.1 \mathrm{bA}$ & $33.2 \mathrm{bA}$ & $28.6 \mathrm{cA}$ & $29.9 \mathrm{cA}$ \\
\hline & \multicolumn{6}{|c|}{ Seed size (grader inlet perfuration) $6.5 \mathrm{~mm}$} \\
\hline Seed Size grader outlet & $30.6 \mathrm{bB}$ & $36.7 \mathrm{aA}$ & $33.9 \mathrm{aA}$ & $33.3 \mathrm{aA}$ & $28.5 \mathrm{bA}$ & $31.7 \mathrm{bA}$ \\
\hline Gravity table inlet & $30.8 \mathrm{bB}$ & $38.7 \mathrm{aA}$ & $34.1 \mathrm{bA}$ & $33.2 \mathrm{bA}$ & $30.0 \mathrm{bA}$ & $31.8 \mathrm{bA}$ \\
\hline Gravity table outlet & $30.2 \mathrm{cA}$ & $40.1 \mathrm{aA}$ & $34.4 \mathrm{bA}$ & $34.7 \mathrm{bA}$ & $31.1 \mathrm{cA}$ & $34.4 \mathrm{bA}$ \\
\hline Holding bin & $32.1 \mathrm{bA}$ & $38.5 \mathrm{aA}$ & $32.5 \mathrm{bA}$ & $34.3 \mathrm{bA}$ & $32.2 \mathrm{bA}$ & $31.6 \mathrm{bA}$ \\
\hline \multirow[t]{2}{*}{ Bagging scale } & $30.5 \mathrm{bA}$ & $37.6 \mathrm{aA}$ & $35.3 \mathrm{aA}$ & $35.7 \mathrm{aA}$ & $29.8 \mathrm{bA}$ & $31.2 \mathrm{bA}$ \\
\hline & \multicolumn{6}{|c|}{ Seed size (grader inlet perfuration) $5.5 \mathrm{~mm}$} \\
\hline Seed Size grader outlet & $26.5 \mathrm{cA}$ & $36.0 \mathrm{aA}$ & $32.7 \mathrm{aA}$ & $31.0 \mathrm{bA}$ & $27.6 \mathrm{cA}$ & $29.9 \mathrm{bA}$ \\
\hline Gravity table inlet & $27.8 \mathrm{cA}$ & $36.9 \mathrm{aA}$ & $32.5 \mathrm{bA}$ & $33.8 \mathrm{bA}$ & $29.5 \mathrm{cA}$ & $29.8 \mathrm{cA}$ \\
\hline Gravity table outlet & $30.2 \mathrm{cA}$ & $39.2 \mathrm{aA}$ & $34.9 \mathrm{bA}$ & $33.2 \mathrm{bA}$ & $28.1 \mathrm{cA}$ & $29.9 \mathrm{cA}$ \\
\hline Holding bin & $31.5 \mathrm{cA}$ & $37.5 \mathrm{aA}$ & $33.2 \mathrm{bA}$ & $33.7 \mathrm{bA}$ & $27.8 \mathrm{cA}$ & $29.3 \mathrm{cA}$ \\
\hline Bagging scale & $29.1 \mathrm{cA}$ & $36.4 \mathrm{aA}$ & $33.1 \mathrm{bA}$ & $32.9 \mathrm{bA}$ & $27.7 \mathrm{cA}$ & $30.2 \mathrm{cA}$ \\
\hline CV (\%) & 11.47 & & & & & \\
\hline General mean & 32.39 & & & & & \\
\hline
\end{tabular}

Means followed by the same small letter in the same row and the same capital letter in the same column for each response variable are not statistically different between each other by the Scott-Knott test at $5 \%$ probability.

\section{Conclusions}

Based on the results found in this study, it is possible to conclude that the processing resulted in an improvement in the physiological quality of seed lots and is especially efficient for those with intermediate quality; the equipment and the system of transport (lifts and conveyor belts) used in this study did not cause mechanical damages to the seeds; the mechanical damages were mostly detected in larger seeds and stinkbug damages were found in smaller seeds; and seeds with weathering damage were neither eliminated nor reduced by any processing line.

\section{Aknowledgements}

The authors wish to thank Cocari - Cooperativa Agropecuária e Industrial, Embrapa Soja and Universidade Estadual de Maringá for providing the structure for carrying out the study.

\section{References}

CUNHA, J.P.A.R.; OLIVEIRA, P.; SANTOS, C.M.; MION, R.L. Qualidade das sementes de soja após a colheita com dois tipos de colhedora e dois períodos de armazenamento. Ciência Rural, v.39, n.5, p.1420-1425, 2009. http://www.scielo.br/scielo.php?script $=$ sci nlinks\&ref $=000085 \&$ pid $=$ S2317-1537201300030001200007\&lng $=\overline{p t}$

DEPIERI, R.; PANIZZI, A.R. Duration of feeding and superficial and in-depth damage to soybean seed by selected species of stink bugs (Heteroptera: Pentatomidae). Neotropical Entomology, v.40, p.197-203, 2011. http://www.scielo.br/pdf/ne/v40n2/07.pdf

BRASIL. Ministério da Agricultura, Pecuária e Abastecimento. Regras para análise de sementes [Rules for seed testing]. Ministério da Agricultura, Pecuária e Abastecimento. Secretaria de Defesa Agropecuária. Brasília: MAPA/ACS, 2009. 395p. 2009.

FERREIRA, D.F. Sisvar: a computer statistical analysis system. Ciência e Agrotecnologia, v.35, n.6, p.1039-1042, 2011. http://www. scielo.br/pdf/cagro/v35n6/a01v35n6.pdf

FERREIRA, R.L.; SÁ, M.E. Contribuição de etapas do beneficiamento na qualidade fisiológica de sementes de dois híbridos de milho. [Contribution of the processing stages on physiological quality of two maize hibrids]. Revista Brasileira de Sementes, v.32, n.4, p.99110, 2010. https://repositorio.unesp.br/handle/11449/28170 
FESSEL, S.A.; SADER, R.; PAULA, R.C.; GALLI, J.A. Avaliação da qualidade física, fisiológica e sanitária de sementes de milho durante o beneficiamento. [Evaluation of physical, physiological and sanitary quality of maize seeds during processing]. Revista Brasileira de Sementes, v.25, n.2, p.70-76, 2003. http://www.scielo. br/pdf/\%0D/rbs/v25n2/19651.pdf

FRANÇA-NETO, J.B.; KRZYZANOWSKI, F.C.; COSTA, N.P. $O$ teste de tetrazólio em sementes de soja. Londrina: Embrapa-CNPSo, 72p, (Série Documentos, 116), 1998.

FRANÇA-NETO, J.B.; KRZYZANOWSKI, F.C.; COSTA, O.; COSTA, N.P.; HENNING, A.A. Classificação por densidade da semente de soja e sua qualidade fisiológica. In: Congresso Brasileiro de Soja, 4., Londrina. Resumos... Londrina: Embrapa Soja, p.190-191, 2006.

GRIS, C.F.; VON PINHO, E.V.R.; ANDRADE, T.; BADONI, A.; CARVALHO, M.L.M. Qualidade fisiológica e teor de lignina no tegumento de sementes de soja convencional e transgênica RR submetidas a diferentes épocas de colheita. Ciência $e$ Agrotecnologia, v.34, n.2, p.374-381, 2010. http://www.scielo.br/ pdf/cagro/v34n2/15.pdf

HESSE, S.R.; PESKE, S.T. Separador em espiral para remoção de sementes de feijão miúdo em sementes de soja. Tecnologia de Sementes, v.1, n.2, p.118, 1981.

JUVINO, A.N.K.; RESENDE, O.; COSTA, L.M.; SALES, J.F. Vigor da cultivar BMX Potência RR de soja durante o beneficiamento e períodos de armazenamento. Revista Brasileira de Engenharia Agrícola e Ambiental, v.18, n.8, p.844-850, 2014. http://www.scielo. br/pdf/rbeaa/v18n8/v18n08a10.pdf

KRZYZANOWSKI, F.C.; FRANÇA-NETO, J.B.; HENNING, A.A. Relato dos testes de vigor disponíveis para as grandes culturas. Informativo ABRATES, v.1, n.2, p.15-50, 1991.

LOPES, M.M.; PRADO, M.O.D.; SADER, R.; BARBOSA, R.M. Efeitos dos danos mecânicos e fisiológicos na colheita e beneficiamento de sementes de soja. Bioscience Journal, v.27, p.230238, 2011. http://www.seer.ufu.br/index.php/biosciencejournal/ article/view/7123/7228

MARCOS-FILHO, J. Fisiologia de sementes de plantas cultivadas. $2^{\mathrm{a}}$ edição. Londrina: ABRATES, 2015. 659p.

MARYAM, D.; OSKOUIE, B. Study the effect of mechanical damage at processing on soybean seed germination and vigor. Journal of Agricultural and Biological Science, v.6, p.60-64, 2011. http://www. arpnjournals.com/jabs/research_papers/rp_2011/jabs_0711_294.pdf

MOREANO, T.B.; BRACCINI, A.L.; SCAPIM, C.A.; KRZYZANOWSKI, F.C.; FRANÇA-NETO, J.B.; MARQUES, O.J. Changes in the effects of weathering and mechanical damage on soybean seed during storage. Seed Science and Technology, v.39 n.3, p.604-611, 2011. http://www.ingentaconnect.com/contentone/ ista/sst/2011/00000039/00000003/art00007
MOREANO, T.B.; BRACCINI, A.L.; SCAPIM, C.A.; FRANÇANETO, J.B.; KRZYZANOWSKI, F.C.; MARQUES, O.J. Physical and physiological qualities of soybean seed as affected by processing and handling. Journal of Seed Science, v.35, n.4, p.466-477, 2013. http://www.scielo.br/pdf/jss/v35n4/08.pdf

NEVES, J.M.G.; OLIVEIRA, J.A.; SILVA, H.P.; REIS, R.G.; ZUCHI, J.; VIEIRA, A.R. Quality of soybean seeds with high mechanical damage index after processing and storage. Revista Brasileira de Engenharia Agrícola e Ambiental, v.20, n.11, p.10251030, 2016. http://www.scielo.br/pdf/rbeaa/v20n11/1415-4366rbeaa-20-11-1025.pdf

PARDE, S.R.; KAUSAL, R.T.; JAYAS, D.S.; WHITE, N.D.G. Mechanical damage to soybean seed during processing. Journal of Stored Products Research, v.38, n.4, p.385-394, 2002. https:// www.sciencedirect.com/science/article/pii/S0022474X01000406/ pdfft?md5=60844dcd796f9b4f9f1119c3925917af\&pid=1-s2.0S0022474X01000406-main.pdf

SCOTT, A.; KNOTT, M. Cluster-analysis method for grouping means in analysis of variance. Biometrics, v.30, n.3, p.507-512, 1974.

SILVA, R.P.; TEIXEIRA, I.R.; DEVILLA, I.A.; REZENDE, R.C.; SILVA, G.C. Qualidade fisiológica de sementes de soja (Glycine max L.) durante o beneficiamento. Semina: Ciências Agrárias, v.32, p.1219-1230, 2011. http://www.uel.br/revistas/uel/index.php/ semagrarias/article/view/4731/8887

SILVA, F.A.C.; SILVA, J.J.; DEPIERI, R.A.; PANIZZI, A.R. Feeding activity, salivary amilase activity and superficial damage to soybean seed by adult Edessa meditabunda (F.) and Euschistus heros (F.) (Hemiptera: Pentatomidae). Neotropical Entomology, v.41, p.386-390, 2012. https:// link.springer.com/content/pdf/10.1007\%2Fs13744-012-0061-9.pdf

SCHUCH, L.O.B.; KOLCHINSKI, E.M.; FINATTO, J.A. Qualidade fisiológica da semente e desempenho de plantas isoladas de soja. Revista Brasileira de Sementes, v.31, n.1, p.144-149, 2009. http:// www.scielo.br/pdf/rbs/v31n1/a16v31n1.pdf

TERASAWA, J.M.; PANOBIANCO, M.; POSSAMAI, E.; KOEHLER, H.S. Antecipação da colheita na qualidade fisiológica de sementes de soja. Bragantia, v.68, n.3, p.765-773, 2009. http:// www.scielo.br/pdf/brag/v68n3/a25v68n3.pdf 